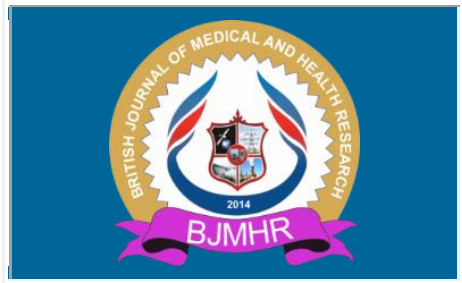

\title{
BJMHR
}

British Journal of Medical and Health Research

Journal home page: www.bjmhr.com

\section{SARS-COV-2 Pandemic in Syria: Symptoms and Treatments}

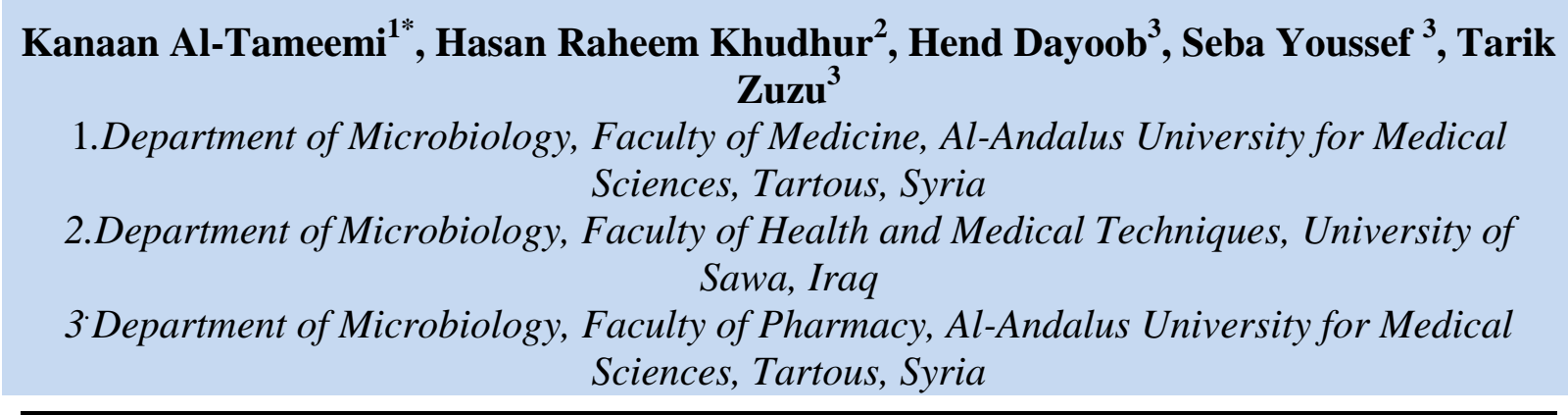

\section{ABSTRACT}

SARS-CoV-2 has caused global pandemic that resulted in a dramatic loss of human life worldwide. The first human case was reported in December 2019 in China, and while the first case in Syria was confirmed on March 2020. By July 1st, 2021, 25551 cases were reported in Syria with 1879 deaths. The most common symptoms of covid-19 are fever, dry cough, and shortness of breath. Some patients may endure from musculoskeletal, gastrointestinal and dermatologic symptoms. Many drugs (including antibiotics, corticosteroids, antiviral and Immunomodulatory drugs) have been evaluated and recommended to be used in COVID-19 treatment, resulting in clinical recovery.

Keywords: SARS-CoV-2, Syria, pandemic, remdesivir, corticosteroids, antiviral 


\section{INTRODUCTION}

The world faced several epidemics and pandemics that affected millions of lives. Despite the advanced level in medicine and science humans reach, new pathogens pose threats to their lives, global economic security and healthcare systems ${ }^{1,2}$.

Coronaviruses (CoVs) represent a large family of enveloped, positive single-stranded RNA viruses. They infect a wide variety of animals, including humans, causing respiratory, enteric, hepatic and neurological diseases. CoVs are divided into four subfamilies: alpha-, beta-, gamma- and delta-coronavirus ${ }^{3}$. Alpha- and beta-coronaviruses arise from mammals, principally bats, causing more severe and fatal diseases to humans, whereas gamma- and delta- coronaviruses mainly arise from birds and pigs and cause asymptomatic or mild disease to humans ${ }^{1,4}$.

To date, seven human coronaviruses are known, including: HCoV-229E, HCoV-OC43, HCoV-HKU1, HCoV-NL63, MERS-COV, SARS-CoV and the most lately discovered, SARS-COV-2, which is called COVID- $19^{5}$. Coronaviruses have infected humans twice in the last two decades that led to major epidemics ${ }^{3,6}$.

Over 2002-2003, Severe Acute Respiratory Syndrome (SARS) spread to more than 30 countries affecting over 8,000 patients across five continents and killing 774 of them ${ }^{6,7,8}$. Since 2012, Middle East Respiratory Syndrome (MERS) spread to 27 countries affecting 2494 patients and killing 858 of them ${ }^{6,9,10}$.

\section{Sars-COV-2 structure}

CoVs have the largest genomes (26-32 kb) among all RNA viruses' families ${ }^{11}$. SARS-CoV-2 belongs to the beta-coronavirus group and shares $\sim 75-80 \%$ of its viral genome with SARSCoV. It is spherical virion with a core shell and a surface that is similar to a solar corona based on its surface protein projections, which give the version its name (Latin: corona = crown) ${ }^{1,4,12}$.

SARS-CoV-2 possesses four essential proteins: spike (S), membrane (M), envelope (E) and nucleocapsid (N) (Figure 1). S protein plays a crucial role in the viral attachment to the cell membrane receptor, membrane fusion, and eventually viral entry into the host cell. $\mathrm{M}$ and $\mathrm{E}$ proteins are responsible for the coronavirus envelope formation, while $\mathrm{N}$ protein, which combines with the genome RNA to form the helical nucleocapsid, is responsible for transcription increment and virus assembly $1,10,11,13$. 


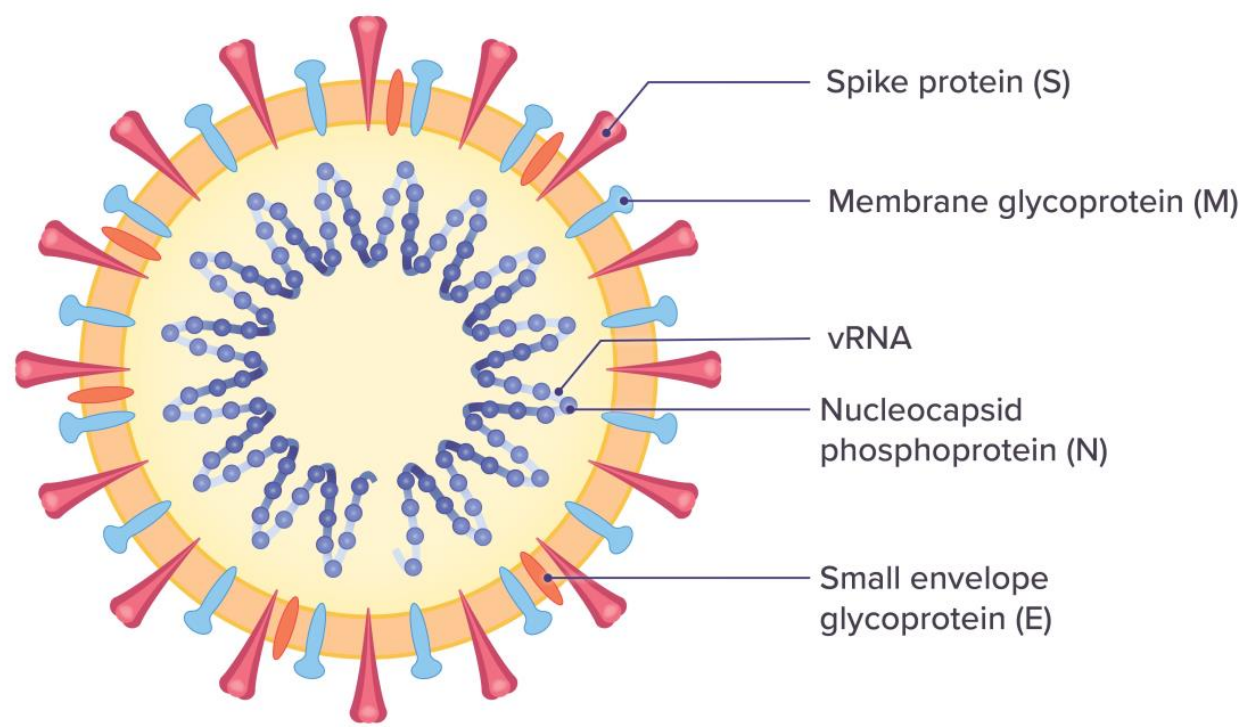

Figure 1: SARS-CoV-2 structure ${ }^{1}$

\section{Timeline to SARS-CoV-2 (COVID-19) pandemic}

It is postulated that the outbreak for SARS-CoV-2 started in Wuhan around December $12^{\text {th }}$, 2019, with multiple patients having similar clinical symptoms (cough, fever, dyspnoea and atypical pneumonia). Then, on December $29^{\text {th }}$, four cases of "pneumonia of unknown aetiology" were reported by local Chinese hospitals, and all of them were thought to have a connection to a local seafood market that sold live non-aquatic wild animals ${ }^{1}$.

The Chinese authorities alerted the World Health Organization (WHO) of these cases on December $31^{\text {st }}$. Then, the Chinese Centre for Disease Control and Prevention (China CDC) upgraded the emergency response to Level 2 on January $6^{\text {th }}, 2020$. After that, the first case outside of China was reported in Thailand on January $13^{\text {th }}$. On January $15^{\text {th }}$, China CDC elevated the emergency response to Level 1. Over time, SARS-CoV-2 spread to all continents, which forced WHO to announce the pandemic state on March $11^{\text {th }} 1,13$.

By June $29^{\text {th }}$, more than 180 million cases have been reported and almost 4 million death ${ }^{14}$.

\section{SARS-CoV-2 (COVID-19) pandemic in Syria}

Several cases of COVID-19 were reported earlier in Lebanon, Jordan and Iran. However, the spread of the virus was late in Syria. The first COVID-19 case in Syria was confirmed on March $22^{\text {nd }}, 2020$, and a week later, the first death was reported. The disease has spread rapidly. The case numbers increased to 328 with 10 deaths by July $03^{\text {rd }}, 2020$, according to the Syrian Ministry of Health ${ }^{15}$.

There were some doubts about the accurateness of these figures, because of the limited testing capabilities and limited resources. Syrian Health Ministry in Damascus conducted almost one hundred tests daily. However as a consequence of testing kits shortage, the tests were available only to people with clear symptoms, or previous contact with confirmed cases or deaths ${ }^{15}$. 
COVID-19 was expected to be a great challenge to the Syrian health system after several years of war. Hence, the WHO warned that Syria is at high risk of a major outbreak due to the lack of sufficient equipment and the loss of nearly $70 \%$ of health care workers ${ }^{15}$.

In order to stem the spread of COVID-19, strict measurements were imposed by the Syrian government, similar to those adopted by other countries. Thus, a partial lockdown was imposed from $6 \mathrm{pm}$ to $6 \mathrm{am}$, with a complete closure of parks, markets, shops, and public transport. Classes at schools and universities were postponed for a while. Traveling between cities was banned, and all flights were suspended. In addition, full lockdown was posed on areas and neighbourhoods that contain confirmed or suspected infections or deaths. On May $26^{\text {th }}$, the government gradually loosed the curfew restrictions due to the deterioration in economy ${ }^{15,16}$.

The number of reported cases rose to 25551 cases (21831 recovered and 1879 deaths) on July $1^{\text {st }}, 2021$. Figures 2, 3 and 4 show the increment of COVID-19 cases in Syria, daily new cases and new deaths, respectively, from the beginning of the outbreak until the end of June 2021. By July $1^{\text {st }}, 21831$ patients have recovered from COVID-19. The majority of them were under 69 years and did not have any other diseases (Figure 5) ${ }^{17}$.

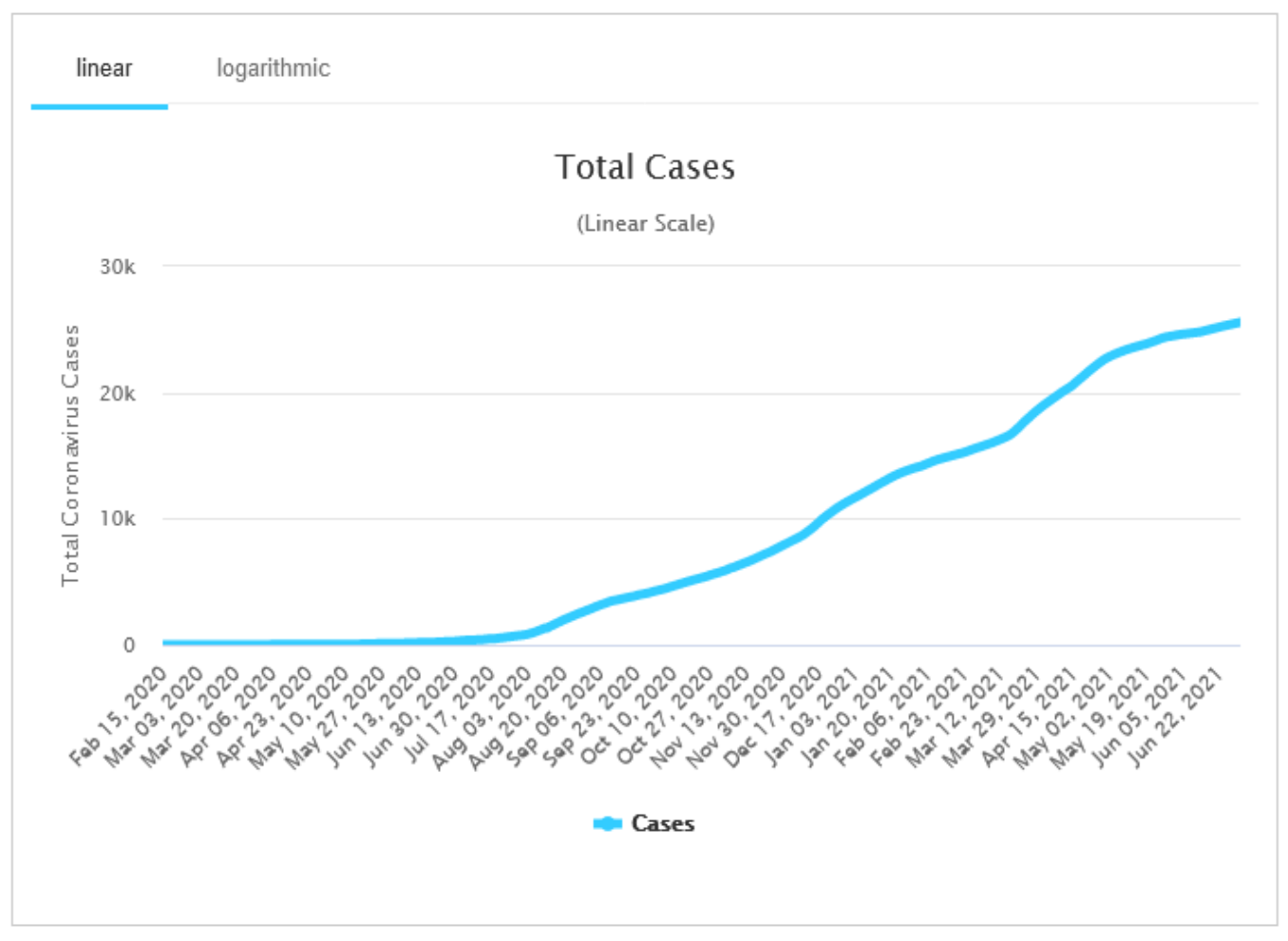

Figure 2: Total cases of COVID-19 in Syria ${ }^{54}$ 


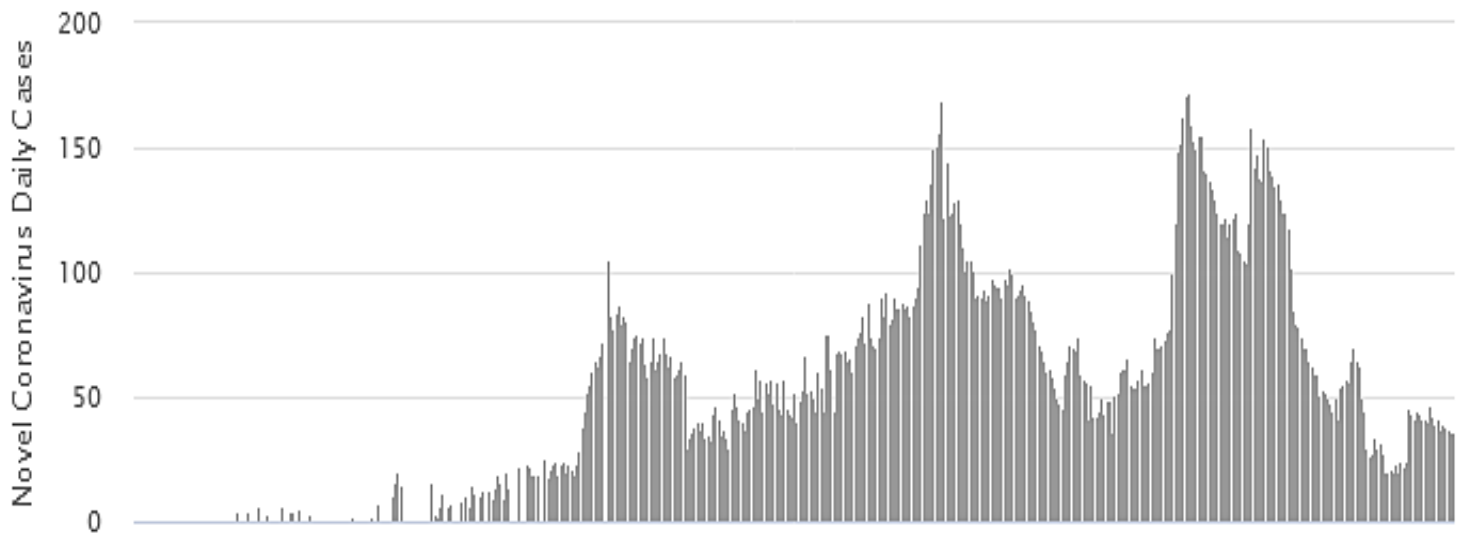

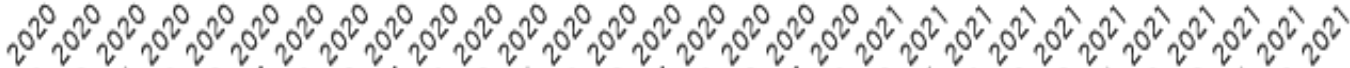

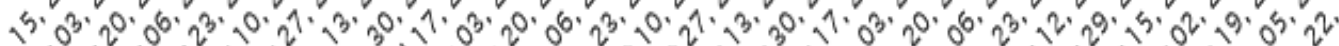

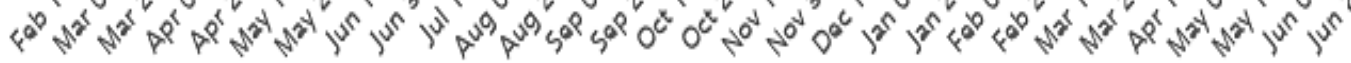

Daily Cases $\quad \rightarrow 3$-day moving average $\quad \square \diamond 7$-day moving average

Figure 3: Daily cases of COVID-19 in Syria ${ }^{54}$

\section{Deaths per Day \\ Data as of 0:00 GMT+8}

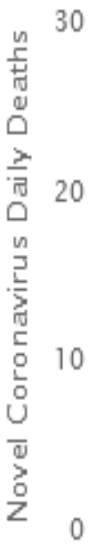

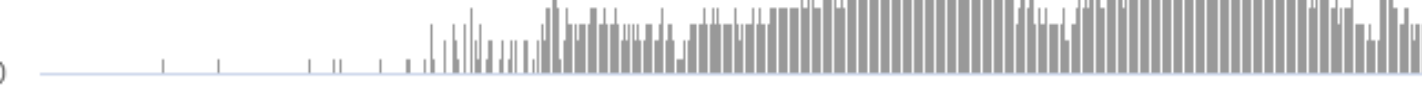

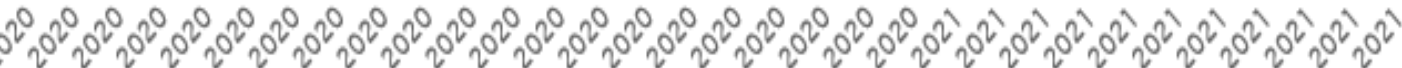

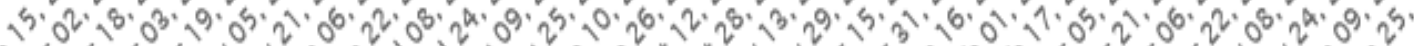

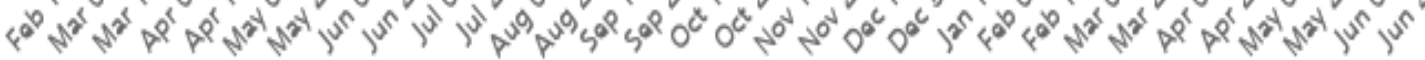

Daily Deaths $\bullet-3$-day moving average $\square \multimap 7$-day moving average

Figure 4: Daily deaths of COVID-19 in Syria ${ }^{54}$ 


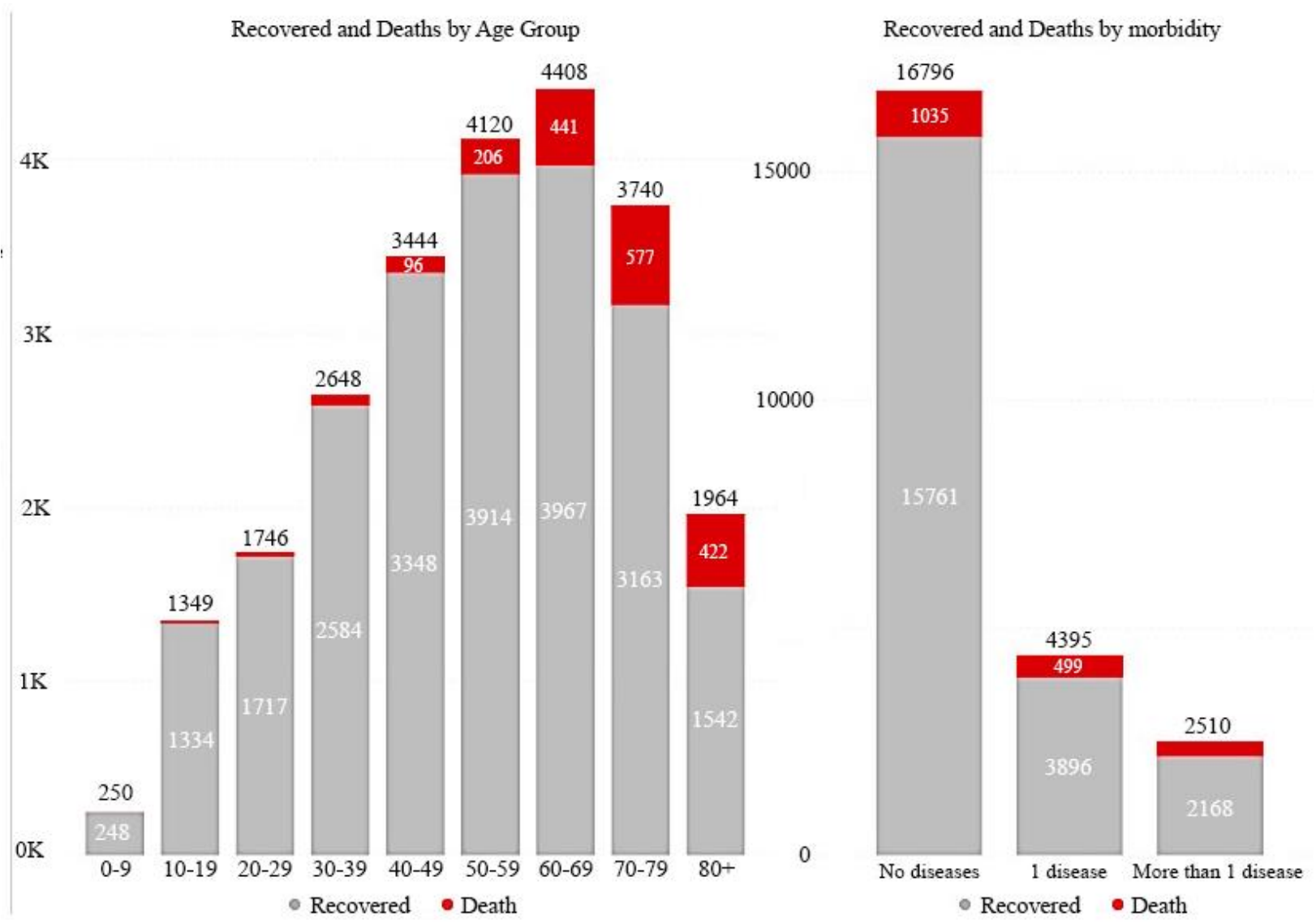

Figure 5: Recovered cases of COVID-19 in Syria by age group and morbidity ${ }^{17}$

As for the distribution of COVID-19 in the Syrian governorates (excluding Idleb), Damasscus ranked first (5606 cases) followed by Aleppo (3938 cases) and Lattakia (3896 cases) as shown in Table $1^{17}$.

Table 1: Total cases of COVID-19 in Syria according to governorates ${ }^{17}$

\begin{tabular}{lcccccccc} 
Governorates & Total cases & Active & Recovered & Death & New cases & New recovered & New deaths & CFR \\
\hline Damascus & 5,606 & 386 & 4,618 & 602 & 15 & 1 & 0 & $10.74 \%$ \\
\hline Aleppo & 3,938 & 534 & 3,149 & 255 & 17 & 2 & 2 & $6.48 \%$ \\
\hline Lattakia & 3,896 & 295 & 3,376 & 225 & 4 & 2 & 0 & $5.78 \%$ \\
\hline Homs & 3,022 & 134 & 2,594 & 294 & 0 & 0 & 0 & $9.73 \%$ \\
\hline Rural Damascus & 2,581 & 100 & 2,445 & 36 & 0 & 0 & 0 & $1.39 \%$ \\
\hline Tartous & 1,856 & 42 & 1,612 & 202 & 0 & 1 & 1 & $10.88 \%$ \\
\hline Dar'a & 1,322 & 56 & 1,202 & 64 & 0 & 0 & 0 & $4.84 \%$ \\
\hline As-Sweida & 1,292 & 69 & 1,140 & 83 & 0 & 0 & 0 & $6.42 \%$ \\
\hline Hama & 1,178 & 167 & 971 & 40 & 0 & 0 & 0 & $3.40 \%$ \\
\hline Quneitra & 493 & 21 & 443 & 29 & 0 & 0 & 0 & $5.88 \%$ \\
\hline Deir-ez-Zor & 234 & 21 & 170 & 43 & 0 & 0 & 0 & $18.38 \%$ \\
\hline Al-Hasakeh & 109 & 11 & 94 & 4 & 0 & 0 & 0 & $3.67 \%$ \\
\hline A.r-Raqqa & 24 & 5 & 17 & 2 & 0 & 0 & 0 & $0.00 \%$
\end{tabular}

\section{SARS-CoV-2 (Covid-19) symptoms and clinical features}

The incubation period of COVID-19 is 5-6 days, but can last up to 14 days. During this period, which is called presymptomatic period, the infected individuals can transmit the virus to healthy ones ${ }^{18}$. 
COVID-19 has different degrees of severity, from flu-like symptoms to death ${ }^{19}$. The clinical spectrum of this virus varies from asymptomatic or paucisymptomatic forms to serious forms accompanied with respiratory failure, which necessitates mechanical ventilation and support in an intensive care unit (ICU), and multiorgan and systemic manifestations in terms of sepsis, septic shock, and multiple organ dysfunction syndromes (MODS) ${ }^{20,21}$.

Pneumonia appears to be the most frequent serious symptom. It is characterized mainly by fever, dry cough, dyspnea, and bilateral infiltrates on chest imaging. The less common symptoms usually include sore throat, rhinorrhoea, shortness of breath, headache, fatigue, myalgia and arthralgia and fatigue ${ }^{18,20,22,23,24,25}$. Apart from respiratory and musculoskeletal symptoms some patients may have gastrointestinal ones such as abdominal pain, nausea, vomiting and loose stools 18, 20, 22, 23, 24, 26, 27, 28, 29 .

On the other hand, some COVID-19 patients may endure some dermal lesions. A recent Italian study revealed that more than 20\% of COVID-19 patients had cutaneous manifestation as erythematous rash, urticaria and chickenpox-like vesicles basically in the trunk with little or no itching ${ }^{30}$. In another study, the most observed symptoms were chilblains/pernio-like lesion, erythematous maculopapular rashes, and viral exanthema ${ }^{31}$.

Generally, the cutaneous manifestations of COVID-19 were classified into five main clinical patterns: aculopapules (47\%), pseudo-chilblain (19\%), urticarial lesions (19\%), other vesicular eruptions $(9 \%)$, and livedo or necrosis $(6 \%)^{32,33,34}$.

According to Casas et al. (2020), vesicular eruptions appeared early in the evolution of the disease ( $15 \%$ before other symptoms), whereas pseudo-chilblain pattern frequently appeared late in the course of the COVID-19 disease (59\% after other symptoms) ${ }^{32}$.

Moreover, some COVID-19 patients may have complications, such as acute respiratory distress syndrome (ARDS), acute respiratory failure, sepsis, disseminated intravascular coagulation, acute liver and kidney injury and pulmonary embolism. In rare cases, one can observe rhabdomyolysis, multisystem inflammatory syndrome, aspergillosis, pancreatitis, autoimmune haemolytic anaemia or neurological complications ${ }^{18}$.

The previous complications, such as the excessive production of proinflammatory cytokines (such as interleukin (IL)-1, (IL-6), and tumor necrosis alpha (TNF- $\alpha$ )) all lead to ARDS aggravation and widespread tissue damage causing multiple organ failure and death ${ }^{35,36,37}$. Such complications are mostly linked to the cytokine storm

\section{Pharmacologic treatments for Covid-19}

Agents previously used to treat SARS-CoV and MERS-CoV represent potential candidates to treat COVID-19 ${ }^{38}$. The following classes of drugs are being evaluated or developed for the management of COVID-19: antivirals, antibodies, anti-inflammatory agents, targeted immunomodulatory therapies, anticoagulants, and antifibrotics. 


\section{Antibiotics}

Although it is not always recommended in viral pneumonia, the optimum antibiotic regimen helps to prevent secondary bacterial infections and sepsis. Macrolides like azithromycin are highly efficient in preventing pulmonary infections in viral pneumonias patients, in addition to their important anti-inflammatory effect on the airways ${ }^{18,39,40}$.

\section{Corticosteroids}

Steroids can be used for 3-5 days in patients having gradual deterioration of oxygen saturation, enhanced pro-inflammatory response activation and rapid aggravation of features on chest imaging. Methylprednisolone was the first steroid that used to treat COVID-19 (0.5$1 \mathrm{mg} / \mathrm{kg} / \mathrm{day}$ for moderate cases and 1-2 mg/kg/ day for severe cases). Higher doses were not recommended because of the steroid mediated immunosuppression, which delay the viral clearance $^{18,41,42,43}$.

Lately, dexamethasone is started to be used for reducing mortality in severe and critical cases 18,44

\section{Antiviral drugs}

Remdesivir (CIPREMI/COVIFOR): Remdesivir is a broad-spectrum antiviral drug. It blocks the action of viral RNA- dependent RNA polymerase, which is essential for the virus replication ${ }^{45,46,47}$. It was used to treat the first COVID-19 patient in the USA, who showed speedy improvement after only one day of treatment ${ }^{18,38,48}$.

Remdesivir could be considered for patients with moderate illness (200 mg intravenous over 1-2 hours on the first day, then $100 \mathrm{mg}$ intravenous daily for 5-10 days). However, the contraindications for remdesivir usage include children, pregnant or lactating females, and patients with severe hepatic or renal impairment. Therefore, it should be used to treat hospitalised COVID-19 patients with moderate-to-severe disease, and requiring supplemental oxygen therapy ${ }^{18,38,48}$.

Finally, it should be noted that treatment with remdesivir alone is not adequate because of the high mortality rates ${ }^{18}$.

Lopinavir/ritonavir (KALETRA): LPV inhibits the coronavirus protease activity in vitro and in animal studies and lowers mortality rates. At first, it was thought to be potential treatment option for COVID-19 ${ }^{18}$. However, a recent trial revealed that no benefit was observed with LPV/RTV therapy as compared to routine management protocol ${ }^{18,49}$.

Favipiravir (FABIFLU): Favipiravir shows activity against RNA viruses. It is an RNA polymerase inhibitor preventing the viral ${ }^{18,38,46}$.

Favipiravir was the first approved oral medication for COVID-19 treatment in India (1800 $\mathrm{mg}$ twice on the first day, then $800 \mathrm{mg}$ twice a day up until day 14. It shows a considerable 
improvement in mild to- moderate cases of COVID-19, which is related to rapid decrease in the viral load and the early symptomatic improvement ${ }^{18}$.

Although individual antiviral drugs are slightly effective in mild-to-moderate cases, future strategies should evaluate combination of antiviral agents, or antiviral drugs with other therapeutic protocols, to improve the critical COVID-19 cases ${ }^{18}$.

\section{Immunomodulatory drugs}

Tocilizumab: Tocilizumab is a humanised IgG1 monoclonal antibody, directed against the IL-6 receptor. It could be used to treat patients with moderate disease (with increase in inflammatory markers (IL-6) and oxygen demand) and mechanically ventilated patients who are not responding to therapy. The approved dosage is $8 \mathrm{mg} / \mathrm{kg}$ (maximum $800 \mathrm{mg}$ at one time) given slowly in $100 \mathrm{ml}$ normal saline over one hour. If necessary, it can be repeated once after 12-24 hours. Active tuberculosis and neutropenia are contraindications for treating with tocilizumab. It is worth noting that tocilizumab may decrease the risk of invasive mechanical ventilation or death in COVID-19 patients with severe pneumonia ${ }^{18}$.

Chloroquine and hydroxychloroquine: Chloroquine is an antimalarial drug that has a broadspectrum as antiviral activity. Chloroquine (500 mg every 12 hours) prevents the virus infection by increasing the endosomal $\mathrm{pH}$ required for virus fusion within the cell, and/or blocking SARS-CoV receptor glycosylation. Chloroquine reduce the exacerbation of COVID-19 pneumonia and accelerates viral and symptomatic clearance ${ }^{18,42,50,51}$.

As for hydroxychloroquine (HCQS) (200 mg every 12 hours), it is a better chloroquine analogue with regard to safety and anti-SARS-CoV activity in vitro ${ }^{18}$. Both chloroquine and HCQS have immunomodulatory effects and can to suppress the cytokine storm by reducing the production of several pro-inflammatory cytokines, like IL-1, IL-6, interferon- $\alpha$ and tumour necrosis factor $18,42,52$.

On June $15^{\text {th }}, 2020$, the Food and Drug Administration (FDA) cancelled the emergency use authorization for using HCQ and CQ to treat hospitalized COVID-19 patients, and stated that none of them was efficient in COVID-19 therapy ${ }^{52,53}$.

In fact, Based on the serious cardiac and other potential side effects, the possible benefits of HCQ and CQ may not exceed the potential risks for the authorized use ${ }^{53}$.

\section{CONCLUSION}

Novel types of coronaviruses have become a real threat to human health. SARS-CoV and MERS-CoV outbreaks were contained by the world health systems. However, new emerging coronavirus was identified in 2019 in Wuhan, China. The new Covid-19 is highly contagious and has resulted in a global pandemic. In 2020, many Covid-19 cases were reported in the Middle East countries. Actions were taken by governments to prevent the spread of the virus 
such as full lockdowns and social distancing enforcement. By July 1st, 2021, 25551 cases were reported in Syria with 1879 deaths.

Several drugs were re-proposed to be used as treatment for Covid-19 including azithromycin, remdesivir, tocilizumab, chloroquine and hydroxychloroquine. Clinical evaluation of these drugs was carried out in many countries and some of them have exhibited promising results and led to reduction in mortality rate and decrease the time to recovery.

\section{REFERENCES}

1. Chams N, Chams S, Badran R, Shams A, Araji A, Raad M, Mukhopadhyay S, Stroberg E, Duval EJ, Barton LM, Hajj Hussein, I. COVID-19: a multidisciplinary review. Frontiers in public health. 2020; 8:383.

2. Zhou P, Yang XL, Wang XG, Hu B, Zhang L, Zhang W, Si HR, Zhu Y, Li B, Huang CL, Chen HD, Chen J, Luo Y, Guo H, Jiang RD, Liu MQ, Chen Y, Shen XR, Wang X, Zheng XS, Zhao K, Chen QJ, Deng F, Liu LL, Yan B, Zhan FX, Wang YY, Xiao GF, Shi ZL. A pneumonia outbreak associated with a new coronavirus of probable bat origin. Nature. 2020; 579 (7798): 270-273. DOI: https://doi.org/10.1038/s41586-0202012-7.

3. Yin Y, Wunderink RG. MERS, SARS and other coronaviruses as causes of pneumonia. Respirology. 2018; 23: 130-137. DOI: 10.1111/resp.13196.

4. Velavan TP, Meyer CG. The COVID-19 epidemic. Tropical medicine \& international health. 2020; 25(3): 278 - 280.

5. Hulse JD. Human Coronaviruses: The Deadly Seven. Acta Scientific Microbiology. 2020; 3 (6): 86-89.

6. Ali SA, Baloch M, Ahmed N, Ali AA, Iqbal A. The outbreak of Coronavirus Disease (COVID-19)-An emerging global health threat. Journal of Infection and Public Health. 2020; 13: 644-646.

7. Christian MD, Poutanen SM, Loutfy MR, Muller MP, Low DE. 2004. Severe Acute Respiratory Syndrome. Emerging Infections. 2004; 38: 1420- 1426.

8. Pandurangan V, Wilkins E, Woodhead M. Severe acute respiratory syndrome (SARS): a review. Clinical Medicine. 2004; 4 (2): 152-160.

9. Azhar EI, Hui DSC, Memish ZA, Zumla A. The Middle East Respiratory Syndrome (MERS). Infect Dis Clin N Am. 2019; 33: 891-905. DOI: https://doi.org/10.1016/j.idc.2019.08.001.

10. Al-Tameemi K, Kabakli R. Novel coronavirus (2019-nCoV): Disease briefings. Asian Journal of Pharmaceutical and Clinical Research. 2020; 13 (5): 22-27. 
11. Grudlewska-Buda K, Wiktorczyk-Kapischke N, Wałecka-Zacharska E, Joanna Kwiecinska-Piróg J, Buszko K, Leis K, Juszczuk K, Gospodarek-Komkowska E, Skowron K. SARS-CoV-2-morphology, transmission and diagnosis during pandemic, review with element of meta-analysis. J. Clin. Med. 2021; 10: 1962. https://doi.org/10.3390/jcm10091962.

12. Wua YC, Chena CS, Chana YJ. The outbreak of COVID-19: An overview. J Chin Med Assoc. 2020; 83: 3. DOI: 10.1097/JCMA.0000000000000270.

13. Salahshoori I, Mobaraki-Asl N, Seyfaee A, Nasirabad NM, Dehghan Z, Faraji M, Ganjkhani M, Aziz Babapoor A, Seyede Zahra Shadmehr SZ, Hamrang A. Overview of COVID-19 Disease: Virology, Epidemiology, Prevention Diagnosis, Treatment, and Vaccines. Biologics. 2021; 1: 2-40. DOI: https://doi.org/10.3390/biologics1010002.

14. World Health Organization. COVID-19 Weekly Epidemiological Update. Edition 46, published 29 June 2021.

15. Al-Ahdab, S. Knowledge, Attitudes and Practices (KAP) towards pandemic COVID19 among Syrians. BMC Public Health. 2020; 21: 296. DOI: https://doi.org/10.1186/s12889-021-10353-3.

16. Syria iMMAP DFS COVID-19 Situation Analysis. (Last updated May 2021). 53 pages.

17. World Health Organization. COVID-19 Dashboard- Syria. Available online at https://app.powerbi.com/view?r=eyJrIjoiNmY5OGYzNDYtNjZhMy00MWIyLWIyM zctYzc4MmI3ZDNlODk5IiwidCI6ImY2MTBjMGI3LWJkMjQtNGIzOS04MTBiLT NkYzI4MGFmYjU5MCIsImMiOjh9. (Last updated July $1^{\text {st }}$ 2021).

18. Parasher, A. COVID-19: Current understanding of its pathophysiology, clinical presentation and treatment. Postgraduate medical journal. 2021; 97(1147): 312-320.

19. Yang Y, Peng F, Wang R, Guan K, Jiang T, Xu G, Sun J, Chang C. The deadly coronaviruses: The 2003 SARS pandemic and the 2020 novel coronavirus epidemic in China. Journal of autoimmunity. 2020; 109: 102434.

20. Lupia T, Scabini S, Pinna SM, Di Perri G, De Rosa FG, Corcione S. 2019 novel coronavirus (2019-nCoV) outbreak: A new challenge. Journal of global antimicrobial resistance. 2020; 21: 22-27.

21. Snider B, Patel B, McBean E. Asymptomatic cases, the hidden challenge in predicting COVID-19 caseload increases. Infect. Dis. Rep. 2021; 13: 340-347. DOI: https://doi.org/10.3390/idr13020033.

22. Gandhi RT, Lynch JB, Rio C. Mild or moderate Covid-19. The New England Journal of Medicine. 2020; 383: 1757-1766. DOI: 10.1056/NEJMcp2009249. 
23. Lia Y, Wangb H, Wang F, Dua H, Liua X, Chena P, Wanga Y, Lu X. Comparison of hospitalized patients with pneumonia caused by COVID-19 and influenza $A$ in children under 5 years. International Journal of Infectious Diseases. 2020; 98: 80-83.

24. Lima CMAO. Information about the new coronavirus disease (COVID-19). Radiol Bras. 2020; 53(2): V-VI. DOI: http://dx.doi.org/10.1590/0100-3984.2020.53.2e1.

25. Vasiliadis AV, Tsatlidou M, Metaxiotis D, Psomiadis C, Beletsiotis A, Arvaniti K. Non-respiratory symptoms of patients infected with SARS-CoV-2 (Coronavirus Disease 2019): Lessons from their initial presentation at the Hospital. Medicina. 2021; 57: 344. https://doi.org/10.3390/medicina57040344.

26. Kotfis K, Skonieczna-Żydecka K. COVID-19: gastrointestinal symptoms and potential sources of 2019-nCoV transmission. Anaesthesiol Intensive Ther. 2020; 52 (1): 1-2. DOI: https://doi.org/10.5114/ait.2020.93867.

27. Naghma S, Kumar D. Gastrointestinal symptoms in COVID-19 patients: a case series. International Journal of Reproduction, Contraception, Obstetrics and Gynecology. 2020; 9(9): 3866-3869. DOI: http://dx.doi.org/10.18203/2320-1770.ijrcog20203870.

28. Silva FAF, Brito BB, Santos MLC, Marques HS, Júnior RTS, Carvalho LS, Vieira ES, Oliveira MV, Melo FF. COVID-19 gastrointestinal manifestations: a systematic review. Journal of the Brazilian Society of Tropical Medicine. 2020; 53: e20200714. DOI: https://doi.org/10.1590/0037-8682-0714-2020.

29. Zhang J, Garrett S, Sun J. Gastrointestinal symptoms, pathophysiology, and treatment in COVID-19. Genes \& Diseases. 2021; 8: 385e400. DOI: https://doi.org/10.1016/j.gendis.2020.08.013.

30. Recalcati S. Cutaneous manifestations in COVID-19: a first perspective. J Eur Acad Dermatol Venereol 2020; 34:e212-13.

31. Mirza FN, Malik AA, Omer SB, Sethi A. Dermatologic manifestations of COVID-19: a comprehensive systematic review. International Journal of Dermatology. 2021; 60: $418-450$.

32. Casas CG, Catala ACHG, Hernández CG, Rodríguez-Jiménez P, Fernández-Nieto D, Rodríguez-Villa Lario A, Fernández NI, Ruiz-Villaverde R, Falkenhain-López D, Velasco LM, García-Gavín J, Baniandres O, Gonzalez-Cruz C, Norillas-Lahuerta V, Cubiro X, Nart IF, Selda-Enriquez G, Romani J, Fusta-Novel X, Melian-Olivera A, Riesco MR, Burgos-Blasco P, Ortigosa JS, Rodriguez MF, Garcia-Doval I. Classification of the cutaneous manifestations of COVID-19: a rapid prospective nationwide consensus study in Spain with 375 cases. British Journal of Dermatology; 2020; 183(1): 71-77. 
33. Estebanez A, Perez-Santiago L, Silva E, Guillen-Climent S,. Garcia- Vazquez A, Ramon MD. Cutaneous manifestations in COVID-19: a new contribution. J Eur Acad Dermatol Venereol. 2020; DOI: https://doi.org/10.1111/jdv.164.

34. Fahmy DH, El-Amawy HS, El-Samongy MA, Fouda AA, Soliman SH, El-Kady A, Farnetani F, Conti A, Zoeir A, Eissa A, Eissa R. COVID-19 and dermatology: a comprehensive guide for dermatologists. Journal of the European Academy of Dermatology and Venereology. 2020; 34(7): 1388-1394.

35. Ragab D, Salah Eldin HS, Taeimah M, Khattab R, Salem R. The COVID-19 Cytokine storm; What we know so far. Frontiers in Immunology. 2020; 11: 1446. DOI: 10.3389/fimmu.2020.01446.

36. Ye Q, Wang B, Mao J. The pathogenesis and treatment of the 'Cytokine Storm' in COVID-19. Journal of Infection. 2020; 80: 607-613.

37. Rowaiye AB, Okpalefe OA, Adejoke OO, Ogidigo JO, Oladipo OH, Ogu AC, Oli, AN, Olofinase S, Onyekwere O, Abubakar AR, Jahan D, Islam S, Dutta S, Haque M. Attenuating the effects of novel COVID-19 (SARS-CoV-2) infection-induced cytokine storm and the implications. Journal of Inflammation Research. 2021; 14: $1487-1510$.

38. Sanders JM, Monogue ML, Jodlowski TZ, Cutrell JB. Pharmacologic treatments for coronavirus disease 2019 (COVID-19): a review. Jama. 2020; 323(18): 1824-1836.

39. Bacharier LB, Guilbert TW, Mauger DT, Boehmer S, Beigelman A, Fitzpatrick AM, Jackson DJ, Baxi SN, Benson M, Burnham CND, Cabana M, Castro M, Chmiel JF, Covar R, Daines M, Gaffin JM, Gentile DA, Holguin F, Israel E, Kelly HW, Lazarus SC, Lemanske Jr RF, Ly N, Meade K, Morgan W, Moy J, Olin T, Peters SP, Phipatanakul W, Pongracic JA, Raissy HH, Ross K, Sheehan WJ, Sorkness C, Szefler SJ, Teague WG, Thyne S, Martinez FD. Early administration of azithromycin and prevention of severe lower respiratory tract illnesses in preschool children with a history of such illnesses a randomized clinical trial. JAMA. 2015; 314(19): 20342044. DOI:10.1001/jama.2015.13896.

40. Echeverría-Esnal D, Martin-Ontiyuelo C, Navarrete-Rouco ME, Cuscó MD, Ferrández O, Horcajada JP, Grau S. Azithromycin in the treatment of COVID-19: a review. Expert Rev Anti Infect Ther. 2021; 19 (2):147-163. DOI: $10.1080 / 14787210.2020 .1813024$.

41. Yang R, Xiong $\mathrm{Y}$, Ke $\mathrm{H}$, Chen $\mathrm{T}$, Gao S. The role of methylprednisolone on preventing disease progression for hospitalized patients with severe COVID-19. Eur J Clin Invest. 2020; 00: e13412. DOI: 10.1111/eci.13412. 
42. Zhao M. Cytokine storm and immunomodulatory therapy in COVID-19: Role of chloroquine and anti-IL-6 monoclonal antibodies. International Journal of Antimicrobial Agents. 2020; 55: 105982.

43. Maia R, Melo L, Mendes JJ, Freitas PT. Corticosteroids in COVID-19: A doubleedged sword- a retrospective study, Medicina Intensiva. 2021; DOI: 10.1016/j.medin.2021.02.001.

44. The RECOVERY Collaborative Group. Dexamethasone in Hospitalized Patients with Covid-19. The New England Journal of Medicine. 2021; 384 (8): 693-704.

45. Beigel JH, Tomashek KM, Dodd LE, Mehta AK, Zingman BS, Kalil AC, Hohmann E, Chu HY, Luetkemeyer A, Kline S, de Castilla DL, Finberg RW, Dierberg K, Tapson V, Hsieh L, Patterson TF, Paredes R, Sweeney DA, Short WR, Touloumi G, Lye DC, Ohmagari N, Oh M, Ruiz-Palacios GM, Benfield T, Fätkenheuer G, Kortepeter MG, Atmar RL, Creech CB, Lundgren J, Babiker AG, Pett S, Neaton JD, Burgess TH, Bonnett T, Green M, Makowski M, Osinusi A, Nayak S, Lane HC. Remdesivir for the Treatment of Covid-19 - Final Report. The New England Journal of Medicine. 2020; 383 (19): 1813- 1826.

46. Chen PL, Lee NY, Cia CT, Ko1 WC, Hsueh PR. A Review of treatment of coronavirus disease 2019 (COVID-19): Therapeutic repurposing and unmet clinical needs. Frontiers in Pharmacology. 2020; 11: 584956. DOI: 10.3389/fphar.2020.584956.

47. Lam S, Lombardi A, Ouanounou A. COVID-19: A review of the proposed pharmacological treatments. European Journal of Pharmacology. 2020; 886: 173451.

48. Wu PE, Morris AM. Remdesivir for patients with COVID-19. CMAJ. 2021; 193: E125. DOI: 10.1503/cmaj.202505.

49. Cao B, Wang Y, Wen D, Liu W, Wang J, Fan G, Ruan L, Song B, Cai Y, Wei M, Li X, Xia J, Chen N, Xiang J, Yu T, Bai T, Xie X, Zhang L, Li C, Yuan Y, Chen H, Li H, Huang H, Tu S, Gong F, Liu Y, Wei Y, Dong C, Zhou F, Gu X, Xu J, Liu Z, Zhang Y, Li H, Shang L, Wang K, Li K, Zhou X, Dong X, Qu Z, Lu S, Hu X, Ruan S, Luo S, Wu J, Peng L, Cheng F, Pan L, Zou J, Jia C, Wang J, Liu X, Wang S, Wu X, Ge Q, He J, Zhan H, Qiu F, Guo L, Huang C, Jaki T, Hayden GJ, Horby PW, Zhang D, Wang C. A trial of lopinavir-ritonavir in adults hospitalized with severe COVID19. N Engl J Med. 2020; 382: 1787-1799.

50. Gao J, Tian Z, Breakthrough: YX. Chloroquine phosphate has shown apparent efficacy in treatment of COVID-19 associated pneumonia in clinical studies. Biosci Trends. 2020; 14: 72-3. 
51. Saghir SAM, AlGabri NA, Alagawany MM, Attia YA, Alyileili SR, Elnesr SS, Shafi ME, Al-shargi OYA, Al-balagi N, Alwajeeh AS, Alsalahi OS, Patra AK, Khafaga AF, Negida A, Noreldin A, Al-Amarat W, Almaiman AA, El-Tarabily KA, Abd El-Hack ME. Chloroquine and Hydroxychloroquine for the Prevention and Treatment of COVID-19: A Fiction, Hope or Hype? An Updated Review. Therapeutics and Clinical Risk Management. 2021; 17: 371-387.

52. Fatima U, Rizvi SSA, Fatima S, Hassan I. Impact of Hydroxychloroquine/Chloroquine in COVID-19 Therapy: Two Sides of the Coin. Journal of Interferon \& Cytokine Research. 2020; 40 (10): 469-471. DOI: 10.1089/jir.2020.0105.

53. FDA. Coronavirus (COVID-19) update: FDA revokes emergency use authorization for chloroquine and hydroxychloroquine. 2020. Available at https://www.fda.gov/news-events/press-announcements/coronavirus-covid-19-updatefda-revokes-emergency-use-authorization-chloroquine-and (accessed July 3, 2021).

54. https://www.worldometers.info/coronavirus/country/syria/ (Last updated July $1^{\text {st }}$ 2021).

\section{BJMHR is \\ - Peer reviewed \\ - Monthly \\ - Rapid publication \\ - Submit your next manuscript at editor@bjmhr.com

